\title{
Stem Borer (Eldana saccharina W) Infestation Outbreak in Sugarcane Plantations of Northern Ivory Coast: Management Strategies Under Implementation
}

\author{
Crépin Bi Péné ${ }^{1}$, Mélanie Bomo Boua ${ }^{1}$, Yah Coulibaly-Ouattara ${ }^{1}$, François-Régis Goebel ${ }^{2}$ \\ ${ }^{1}$ Research and Development Department, African Sugar Mills in Ivory Coast, Ferké, Ivory Coast \\ ${ }^{2}$ Research Unit of Agro-ecology and Sustainable Intensification of Annual Crops, University of Montpellier, International Center of \\ Agricultural Research for Development, Montpellier, France
}

\author{
Email address: \\ bpene@sucafci.somdiaa.com (C. Bi Péné), cbpene20@yahoo.com (C. Bi Péné)
}

\section{To cite this article:}

Crépin Bi Péné, Mélanie Bomo Boua, Yah Coulibaly-Ouattara, François-Régis Goebel. Stem Borer (Eldana saccharina W) Infestation Outbreak in Sugarcane Plantations of Northern Ivory Coast: Management Strategies Under Implementation. American Journal of Bioscience and Bioengineering. Vol. 6, No. 4, 2018, pp. 20-28. doi: 10.11648/j.bio.20180604.11

Received: November 26, 2018; Accepted: December 13, 2018; Published: January 10, 2019

\begin{abstract}
Heavy stalk borer infestations broke out over the last three cropping seasons in sugarcane plantations of both Ferké sugar mills of Northern Ivory Coast. The study objective was to determine the cause of heavy infestation observed on cane and sugar yields in order to implement a proper pest management strategy. The study which covers from 2006-06 to 2017-18 cropping seasons was based on sampling of all sugarcane plantations at harvest for cane juice analyses and assessment of stalk borer damages in terms of percentage of internodes bored. This allowed to cluster harvested lands depending on the intensity of infested canes and assess the amount of sugar production losses due to E. saccharina. It came out that infestations of this borer observed at harvest broke out only three years ago in Ferké 1 and two years ago in Ferké 2 . Heavy infestations occurred over $45-55 \%$ of the sugarcane area in Ferké 1 as opposed to 25-35\% in Ferké 2. Except for variety SP71-8210, all main sugarcane varieties grown were only heavily infested in Ferké 1. Although infestations were of concern on plantations no matter their water status, they seemed to be much more severe on rainfed and semi-irrigated crops compared to irrigated ones. Sugar production loss due to E. saccharina occurred over the last three years in Ferké 1 as opposed to the last two years in Ferké 2 but more importantly in 2016-17 for both sites with, respectively, a loss of 2600 and 2300 tons of sugar. Significant reduction in sugar production as a result of the limitation in nitrogen fertilizer rates was achieved in 2017-18 compared to 20116-17 by 62 and 50\%, respectively, in Ferké 1 and Ferké 2 . This was one aspect of an integrated stalk borer management strategy to be implemented involving the application of silicone fertilizer, the growing of resistant or tolerant cane varieties and cropping practices preserving natural enemies such as mechanized green harvesting and growing service plants.
\end{abstract}

Keywords: Sugar Yield, Varietal Resistance, Farming Practice, Natural Enemy, Integrated Management

\section{Introduction}

Sugarcane is an economically important crop for food and energy production because of its high capacity of sucrose accumulation in stems and high biomass yield. It is mostly grown in tropical and subtropical areas of the world and stand for number of developing countries as the main source of GDP [1]. In most of these countries, stem borers are economically important pests as they significantly reduce yields of number of food crops such as rice, sorghum, corn and sugarcane [2]. Several species of lepidopteran borers causing such damages belong to genus Chilo, Sesamia, Diatraea and Eldana. The African stalk borer E. saccharina Walker (Lepidoptara: Pyralidae) is known as the main insect pest in sugarcane which larva cause galleries into cane stalks [3-4], especially on their lower parts [5]. These damages on stem tissues being afterwards infected by fungus species (Fusarium spp.) are characterized by a dark-red coloring of surrounding tissues of galleries [6]. E. saccharina damages affect young and adult cane stakes (as opposed to that of other stem borer species like $S$. calamistis, Chilo partellus and $C$. sacchariphagus on young tillers) increase with crop 
age, especially over 12 to 16 months of vegetation [7]. Insecticides were recently used in South Africa to control stem borer damages on reported sugarcane crops as a result of the closing of sugar mills during the summer [8]. Nevertheless, that practice was not unanimously adopted by growers because of the negative impact of pesticides on stem borer natural enemies. According to Betbeder-Matibet [9], $95 \%$ of generation of of $E$. saccharina are eliminated by ants, trichograms, and arachnids. Despite this and the long list of useful biological agents tested [10], the biological control showed its limits in the decrease of stem borer populations to an acceptable economical level. Despite a good knowledge of the insect biology [11-14], much less is known on its behavior in the field over time, on the way it colonizes a newly planted area or a field following sugarcane ratoons. Number of research works carried out over the last 25 years focused on biological control and varietal resistance regarding two major stem borer species, namely $E$. saccharina et $C$. sacchariphagus. If varietal resistance became more successful, it was not the case of biological control which is more difficult to implement, especially on $E$. saccharina [10] cited par Goebel et al [15]. The importance of some farming practices such as nitrogen and silicon fertilizer applications in the control of stem borer populations was reported by several authors [16-22].

The study aimed to analyze heavy infestations of stem borer E. saccharina observed at harvest in sugarcane plantations over the last three cropping seasons (2017-18, 2016-17 and 2015-16) in both Ferké sugarcane growing areas, in order to determine their causes for implementing an appropriate strategy of control.

\section{Material and Methods}

\section{Study site characteristics}

The study was carried out on both sugar mill plantations of Ferké, in northern Ivory Coast $\left(9^{\circ} 20^{\prime}-9^{\circ} 60^{\prime} \mathrm{N}, 5^{\circ} 22^{\prime}-\right.$ $\left.5^{\circ} 40^{\prime} \mathrm{O}, 325 \mathrm{~m}\right)$. The prevailing climate is tropical dry with two seasons: one, starting from November to April, is dry and the other, from May to October, is wet. The dry season is marked by the boreal trade wind which blows over midNovember to late January. The rainfall pattern is unimodal and centered on August and September which total amount of rainfall reaches almost half of the average annual rainfall $(1200 \mathrm{~mm})$ with an average daily temperature of $27^{\circ} \mathrm{C}$. Average maximum and minimum daily air temperatures are 32.5 and $21^{\circ} \mathrm{C}$, respectively. To meet sugarcane crop water requirements, the total amount of irrigation water required reaches $700 \mathrm{~mm} /$ year [23-25]. Both sugarcane growing areas cover around 15500 ha with 10000 ha under irrigation and 3 500 ha of rain-fed village plantations, lie mainly on shallow or moderately deep soils built up on granites. Main soil units encountered are ferralsols and temporally waterlogged soils in valley bottoms of Bandama and Lokpoho river basins with a sandy-clay texture.

Stem borer damage sampling at harvest

Each sugarcane plantation under harvest was sampled in 5 observation plots where 50 millable stalks were randomly chosen and collected per plot, or 150 stalks in total per plantation. Observations consisted in longitudinal splitting of every stalk sampled with a machete in order to determine the percentage of internode and cane damaged or bored (\%INB) by stem borer.

\section{Sucrose analyses at harvest}

Each plantation under harvest was also sampled within 5 observation plots where 6 millable cane stalks were randomly chosen and collected per plot, i.e. 30 stalks per plantation. Prior to sample grinding operation in the laboratory for sucrose analyses, every stalk was cut into 3 pieces of almost equal length while separating them in basal, median and top parts. This allowed to randomly reconstitute 3 batches of 10 stalks for a better homogenization of the initial field sample by permutation of the pieces so that each reconstituted stalk was composed of parts coming from 3 different cane stalks. Eventually, only one batch of 10 reconstituted stalks over 30 (1/3 of initial sample) were grinded for a series of sucrose analyses to determine the sucrose content $(\mathrm{Pol} \% \mathrm{C})$, fiber content (Fiber \%C), juice purity (Purity $\% \mathrm{C}$ ) and recoverable sucrose $(\mathrm{SE} \% \mathrm{C})$. Equipment used comprised a Jefco cutter grinder, a hydraulic press, a refractometer and a polari-meter. Methods used in the determination of required technological parameters were reported by Hoarau [26]. The recoverable sucrose was calculated as follows [16, 27]:

$\mathrm{SE} \% \mathrm{C}=[(0.84 \times \mathrm{Pol} \% \mathrm{C})(1.6-60 /$ Purity $)-(0.05 \times$ Fib \%C)] with:

Purity $\% \mathrm{C}=(\mathrm{Pol}$ juice/Brix $) \times 100$ and Pol juice $=\mathrm{Pol}$ factor $\mathrm{x}$ Pol read.

$\mathrm{Pol} \% \mathrm{C}=\mathrm{N}$ factor $\mathrm{x}$ Pol juice

Factor pol depending on brix value (amount of soluble dry matter in juice measured with a refractometer) is provided by Schmidt table relative to a polarimeter for $26 \mathrm{~g}$ of glucose. The fiber content and $\mathrm{N}$ factor were provided by a table depending on the weight of fiber cake obtained after pressing $500 \mathrm{~g}$ of cane pulp resulting from the grinding operation of every sample of cane stalks.

Assessment of cropped areas infected following the intensity of damage levels

For each Ferké sugarcane mill plantations, a database on history of stem borer damage levels observed at harvest (in \%INB) over 4 cropping seasons was developed. It allowed, depending on the year, to determine by dynamic cross table on Excel the land surface, crop yields and technological quality data regarding the water status of plantations, the main varieties harvested and different levels of stem borer damage. These ones were appreciated following the scale below: $[0 ; 2.5[$ (very low); [2.5; 5.5[ (low); [5.5; 7.5[(average); [7.5; 10.5[ (high); [10.5; 15.5[ (very high); [15.5; 20.5[ (extremely high); [20.5; 25[ (invasive); [25; 30 et plus (very invasive].

\section{Assessment of sucrose lost due to stem borer}

Over 4 cropping seasons considered for each Ferké sugarcane mill plantations (2014-15 to 20117-18), the one which was not significantly affected by stem borer $(\% \mathrm{INB}<5)$ was chose as the reference year for sugar loss/benefit calculations. That was 
the case of 2014-15 and 2015-16 in Ferké 1 and Ferké 2, respectively, with the main hypothesis that damage levels observed did not significantly affect cane yields. Per main variety, the comparison of average cane technological quality data (fiber content, sucrose content, purity and recoverable sucrose) regarding a given year as compared to the reference year allowed to assess the positive or negative impact of stem borer. This was expressed in terms of benefit or loss in recoverable sucrose and therefore sugar yield taking into account the average cane yield obtained. Sugar production benefit or loss was calculated by extrapolating yield benefit or loss to the entire harvested land surface.

\section{Results}

\section{Characterization of climate in line of stem borer biology}

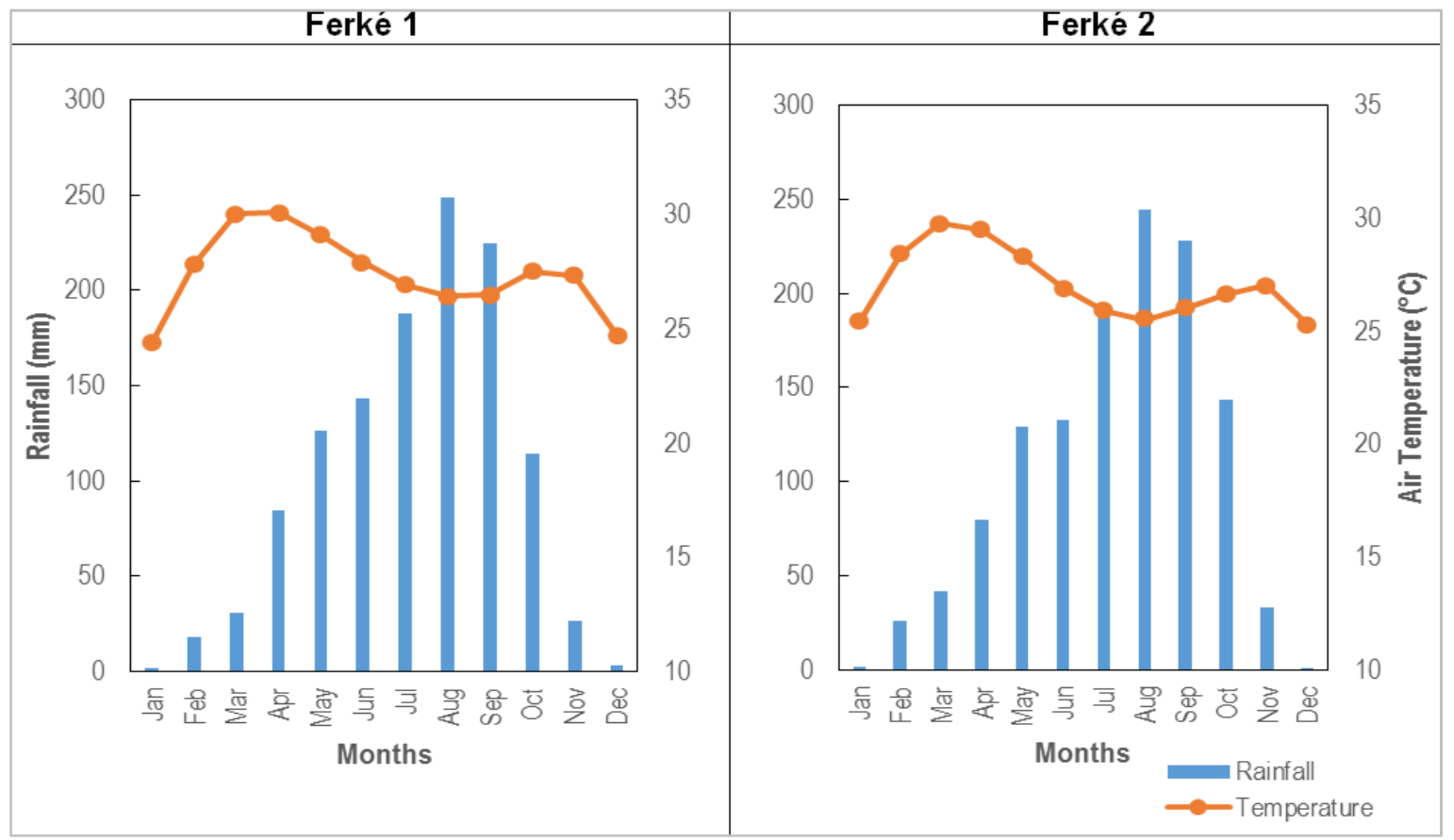

Figure 1. Climate in both Ferké sugar mill plantations in northern Ivory Coast (average rainfall over last 10 years; average daily temperatures over the same decade).

The average annual rainfall recorded daily from about 20 rain gauges distributed across each Ferké sugar mill plantations over the last ten years (2008-2017) gave 1210 \pm 87 and $1250 \pm 86 \mathrm{~mm}$ in Ferké 1 and Ferké 2, respectively (Figure 1). The rainfall pattern centered on August and September is close for both Ferké sugar mill plantations which are located in the same ecological zone marked by a tropical dry climate with mainly a wooded savannah landscape and accessorily some forest landscape in the vicinity of major waterways. The average daily air temperature recorded over the same decade gives $27.4 \pm 1.8$ and $27.0 \pm 1.6^{\circ} \mathrm{C}$ in Ferké 1 and Ferké 2, respectively. These data are in line of the fact that both Ferké sugar mill plantations belong to the same agro-ecological zone, despite the negative impact climate change may have on rainfall pattern. In this context it is sometimes believed that Ferké 1 is more affected than Ferké 2, with a potential influence presumed on the biology of some insect pests like $E$. saccharina. Favorable conditions for stem borer development usually starts in April or May at early rainy season and end in mid-December at early dry season. This period is also favorable for sugarcane growth and development, and therefore potentially risky regarding heavy stem borer damage levels in sugarcane plantations under certain farming conditions and practices such as drop in the population of natural enemies resulting from pesticide applications, cultivation of susceptible cane varieties, high nitrogen fertilizer rates, low silicon content of soils, rainfed crops and unreliable irrigation facilities.

History of stem borer damage levels observed at harvest

Prior to heavy stem borer damage levels observed at harvest in Ferké 1 over 2015-16 cropping season with on average $6.7 \%$ INB, the pest incidence although maintained below the tolerable threshold (5\%) was much more endemic in Ferké 1 with on average 2.6-4.5\% INB compared to $0.9-$ $2 \%$ in Ferké 2 (Figure 2). In Ferké 2, the threshold limit was outclassed in 2016-17 with 5.6\% INB on average. Higher values were reached in 2016-17 in both sugar mill plantations with on average 7.6 and $5.6 \%$ in Ferké 1 and Ferké 2, respectively. A significant reduction of one point in Ferké 1 compared to 0.2 point in Ferké 2 occurred over 2017-18 cropping season. This was partly due to limitations in nitrogen fertilizer rates implemented in 2016-17. It came out that damage levels were above the tolerable limit since the 
last three years in Ferké 1 and the last two years in Ferké 2 later on.

with a negative impact on sugar production to be assessed

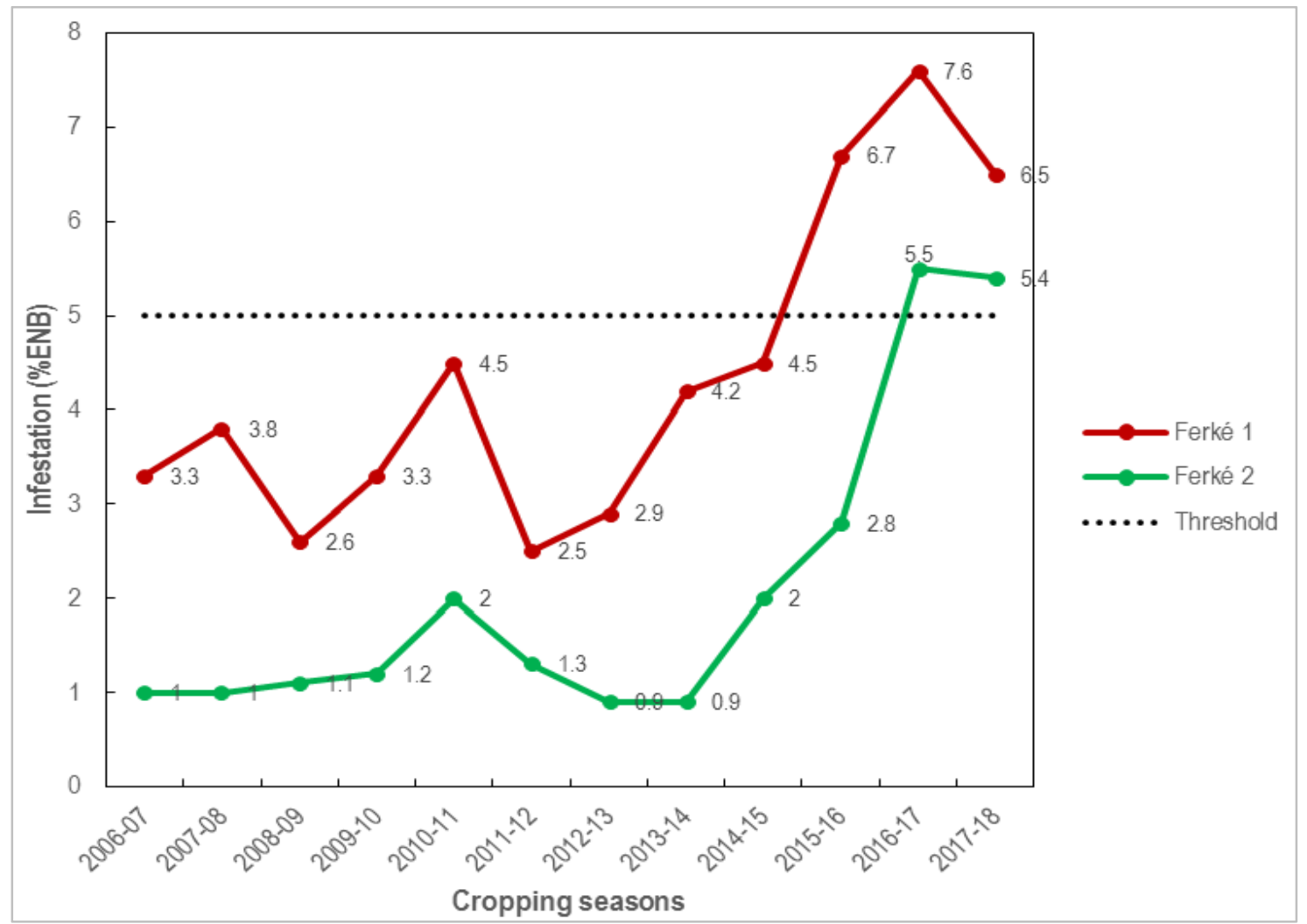

Figure 2. History of E. saccharina average damages observed at harvest in both sugar mill plantations of Ferké, from 2006-07 to 2017-18.

History of cropped areas infected following the intensity of damages

History of stem borer damage levels shows that since 2013-14, Ferké 1 was prone to a phytosanitary status of concern but with a worsening situation over the last three years where $45-55 \%$ of harvested were moderately to very heavily damaged, i.e. over 2700-3300 ha (Figure 3). In Ferké 2 , damage levels became of concern over the last two years where $25-35 \%$ of harvested lands were moderately to very heavily affected, i.e. over 1500-2000 ha.

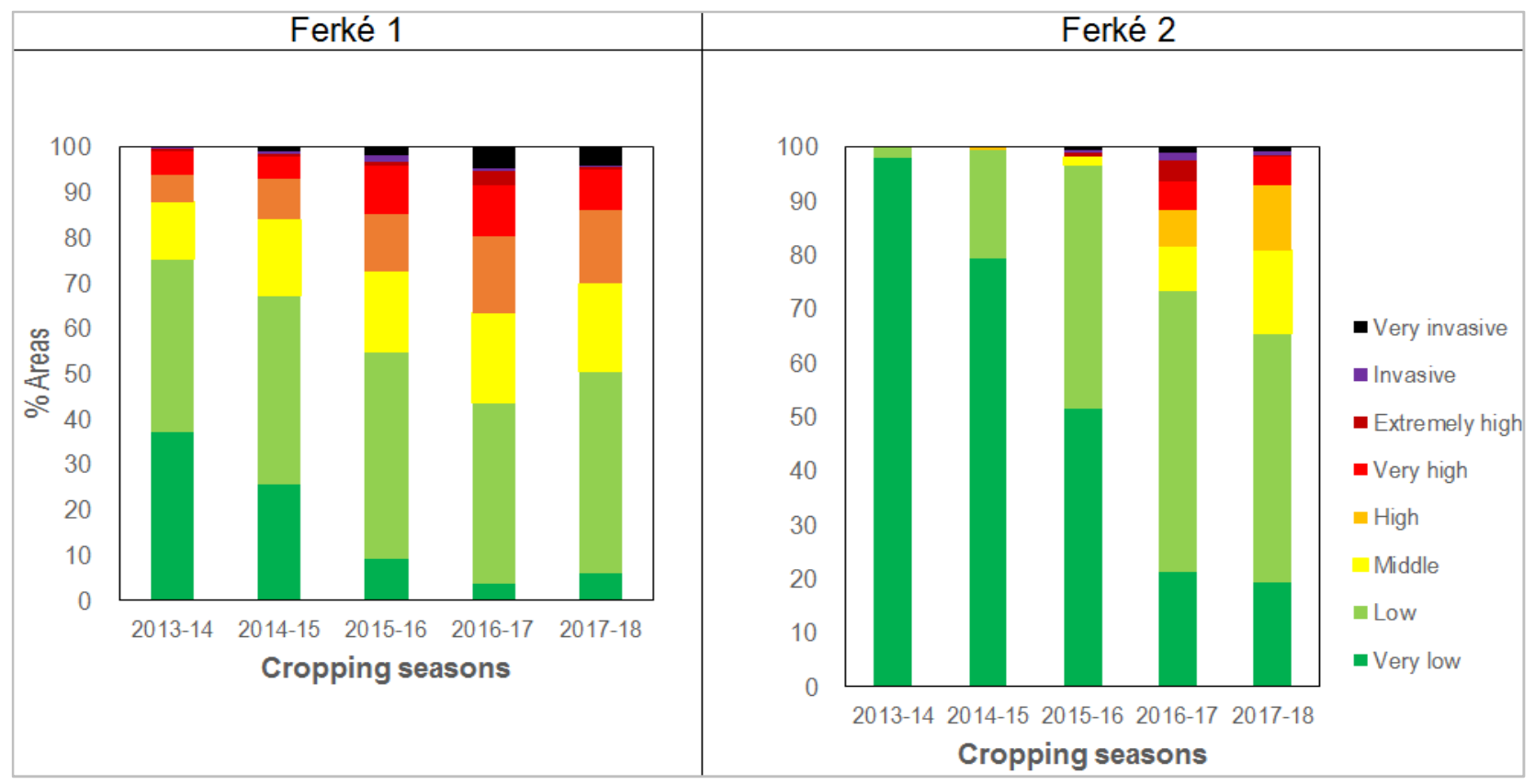

Figure 3. History of E. saccharina infected areas in Ferké 1 and ferké 2 following the intensity of damages, from 2014-15 to 2017-18. 
History of damage levels following water status of plantations

Regardless the water status of sugarcane plantations, stem borer damage levels of concern were observed in Ferké 1 and Ferké 2 over the last three and two cropping seasons, respectively (Figure 4). Nevertheless, the intensity of damage levels was much higher in Ferké 1 compared to Ferké 2, with values ranging from 5.5 to $9 \%$ INB versus 5.3 to $7.7 \%$, respectively. The intensity of damage levels seemed to be higher in rainfed or semi rainfed conditions compared to irrigated plantations. The $2014-15$ cropping season was the least affected by stem borer damages in both sugar mill plantations over the last four years, with average values close to the tolerable limit, i.e. 4.5 and $4.6 \%$ INB in Ferké 1 under irrigation and rainfed conditions, respectively, as opposed to 2 and $1.9 \%$ INB in Ferké 2. The difference between both sugar mill plantations in terms of phytosanitary status was particularly high in 2015-16 where heavy damages broke out in Ferké 1 with $6.7 \%$ INB on average compared to only $2.8 \%$ in Ferké 2.

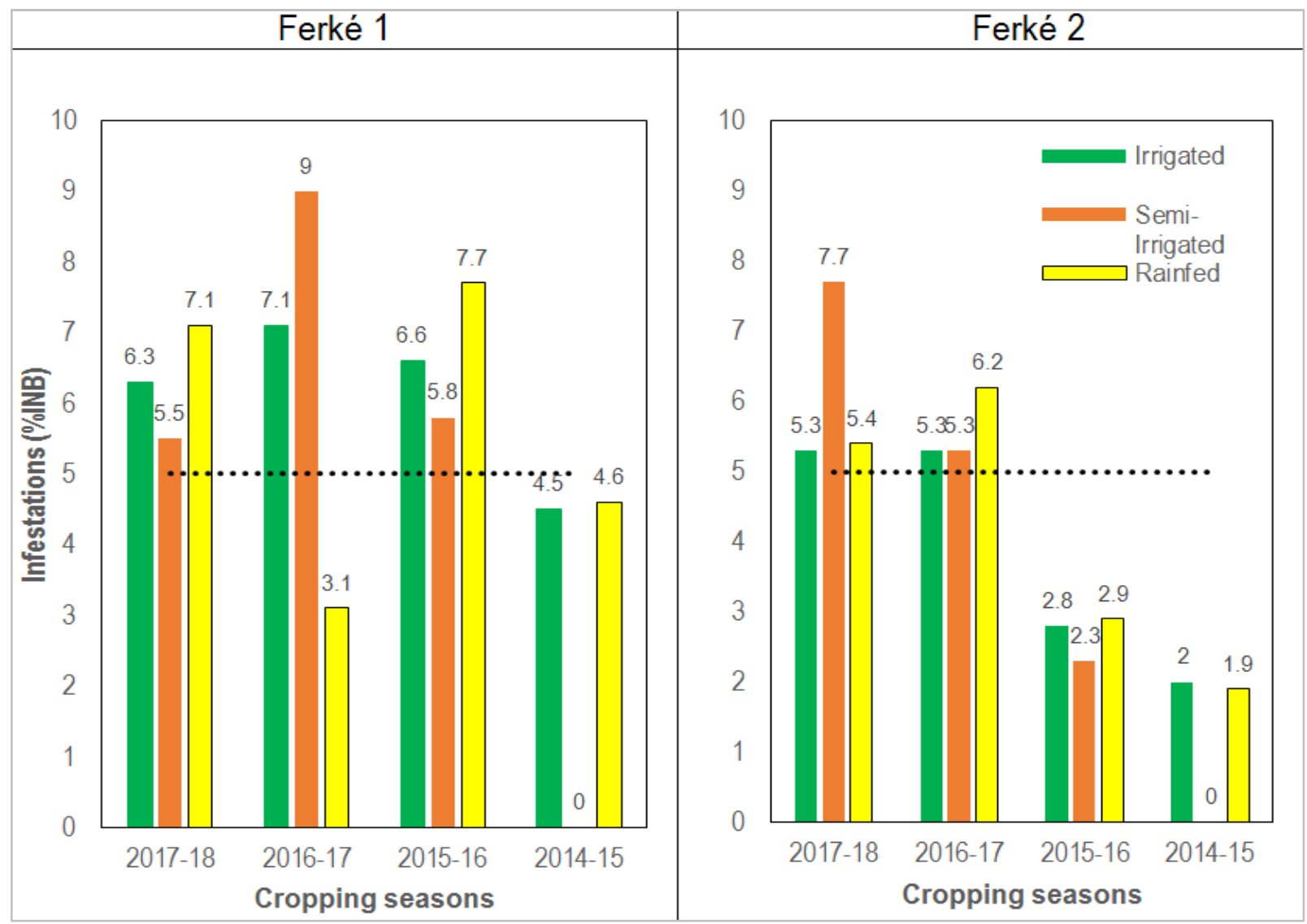

Figure 4. History of E. saccharina damage levels in Ferké 1 and 2 sugar mill plantations following the water status of sugarcane plantations, from 2014-15 to 2017-18.

\section{History of damage levels following main varieties cultivated}

Except for the highly susceptible variety (SP71-8210) to stem borer which was heavily damaged in both sugar mill plantations, all main varieties cultivated were infected only in Ferké 1 over the last three years. Highest damage levels on SP71-8210 variety were observed in Ferké 1, with a significant drop from plant canes to second ratoon canes (from 16 to $9 \%$ INB on average). In this sugar mill plantation, damages on variety R579, as a potentially susceptible material for its low fiber content, dropped gradually since $2015-16$, with 8 to $5.7 \%$ on average.

Stem borer damage levels observed on different varieties in sugarcane nurseries at the age of 10 months over 2016-17 cropping season show a significant difference in both sugar mill plantations which is due to an important difference in fertilizer rates on plant canes (Figure 5). In Ferké 1 where nitrogen rate was $110 \mathrm{~kg} / \mathrm{ha}, 8 \%$ INB on average were observed (all varieties included) as opposed to $70 \mathrm{~kg} / \mathrm{ha}$ in Ferké 2 with only $2 \%$ INB. Therefore, the interaction effect between varieties and $\mathrm{N}$-fertilizer rate is significantly important in plant cane where soil tillage enhances the mineralization of organic nitrogen being contained in organic matter which is added to $\mathrm{N}$ supplied through fertilization. A much lower fertilizer rate in sugarcane nurseries will prevent heavy damages on planting material (cuttings). 


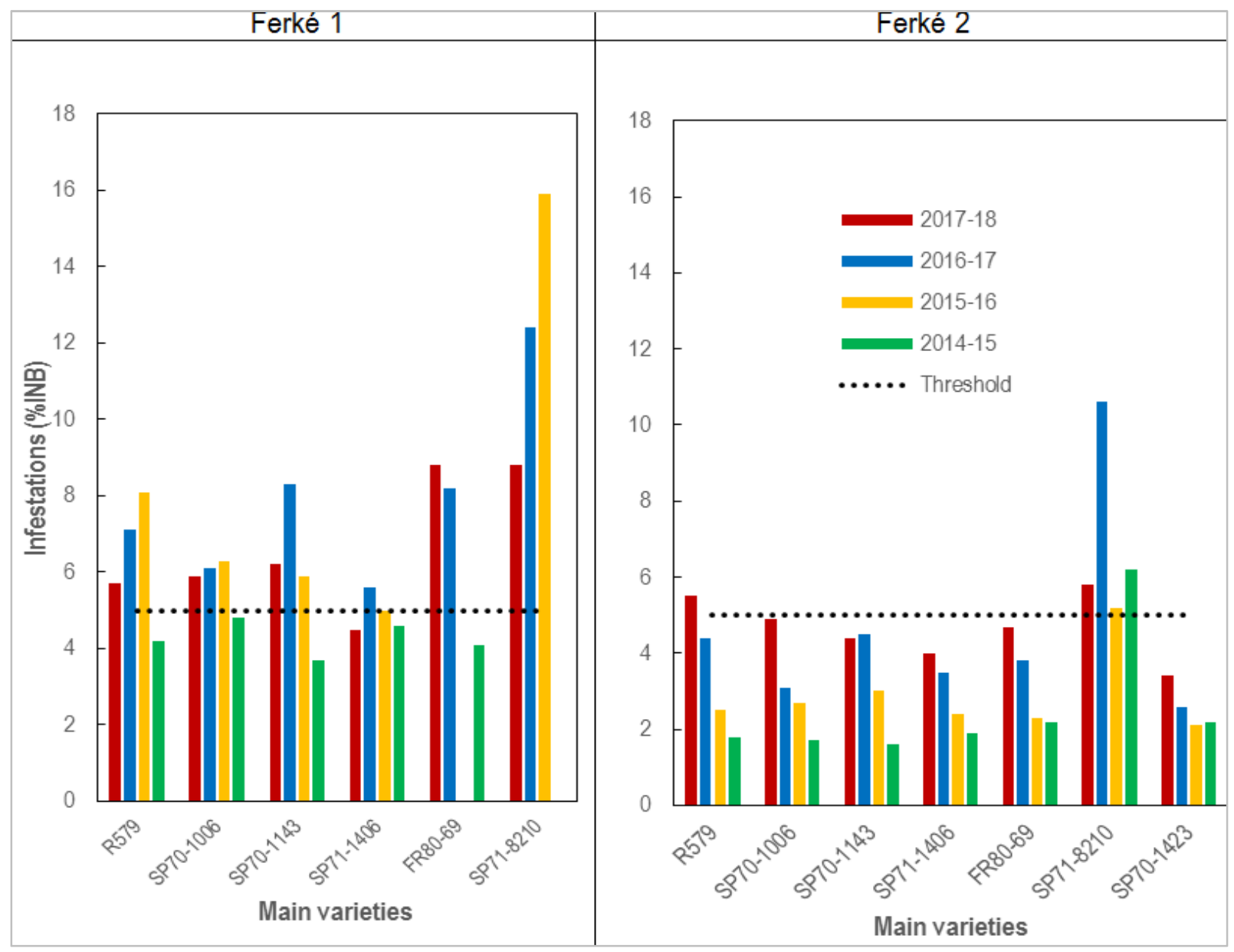

Figure 5. History of E. saccharina damage levels in Ferké 1 and 2 sugar mill plantations on main varieties cultivated, from 2014-15 to 2017-18.

\section{Assessment of sugar losses due to stem borer}

Significant sugar loss due to stem borer in Ferké 1 occurred over the last three years with acuity in 2016-17, resulting in a yield reduction of 0.44 t/ha or a sugar production loss of 2,600 $\mathrm{t}$ (Table 1). Similar loss occurred in Ferké 2 over the last two years with more acuity also in 2016-17, resulting in a sugar yield reduction of $0.36 \mathrm{t} / \mathrm{ha}$ or a production loss of 2,300 t of sugar. In contrast, an increase in sugar yield of $0.10 \mathrm{t} / \mathrm{ha}$ in addition to that of the reference year (2015-16) was obtained in Ferké 2 over 2014-15 cropping season. Table 1 shows that in Ferké 1 , over the period of study the reference year excepted, SP70-1006 was the only cane variety which could tolerate stem borer damages in 2015-16 generating a sugar yield increase of 0.02 t/ha. In Ferké 2, except for the reference year (2015-16) and 2014-15 where stem borer incidence was under control, SP71-8210 was the only cane variety which withstood stem borer in 2017-18 resulting a sugar yield increase of $0.43 \mathrm{t} / \mathrm{ha}$. The N-fertilizer rate limitation policy implemented in 201617 resulted in the reduction of sugar production losses by 62 and 50\% in Ferké 1 and Ferké 2, respectively.

Table 1. Assessment of sugar losses due to stem borer (E. saccharina) on main varieties cultivated in Ferké sugar mill plantations from 2014-15 to 2017-18.

\begin{tabular}{lllllll}
\hline Main varieties & Ferké 1 & & & Ferké 2 & & \\
\hline & $\mathbf{2 0 1 5 - 1 6}$ & $\mathbf{2 0 1 6 - 1 7}$ & $\mathbf{2 0 1 7 - 1 8}$ & $\mathbf{2 0 1 4 - 1 5}$ & $\mathbf{2 0 1 6 - 1 7}$ & $\mathbf{2 0 1 7 - 1 8}$ \\
\hline R579 & -0.50 & -0.64 & -0.17 & 0.68 & -0.47 & -0.19 \\
SP70-1006 & 0.02 & -0.30 & -0.16 & 0.11 & -0.43 & -0.22 \\
SP70-1143 & -0.29 & -0.46 & -0.41 & - & - & - \\
SP71-1406 & -0.02 & -0.28 & -0.14 & -0.05 & -0.26 & -0.27 \\
FR80-69 & - & - & - & 0.02 & -0.17 & -0.15 \\
SP70-1423 & - & - & - & -0.35 & -0.73 & -0.61 \\
SP71-8210 & - & - & - & -0.19 & -0.14 & 0.43 \\
Average (ts/ha) & -0.20 & -0.44 & 5391 & 0.10 & -0.36 & -0.17 \\
Surfaces (ha) & 4333 & 5972 & -992 & 5647 & 5852 & 5641 \\
Losses (ts)* & -856 & -2616 & & 565 & -2341 & -1183 \\
\hline
\end{tabular}

\footnotetext{
*losses extrapolated to each entire farmland harvested in Ferké 1 and Ferké 2.
} 


\section{Discussion}

Influence of fertiliser applications on stem borer damages

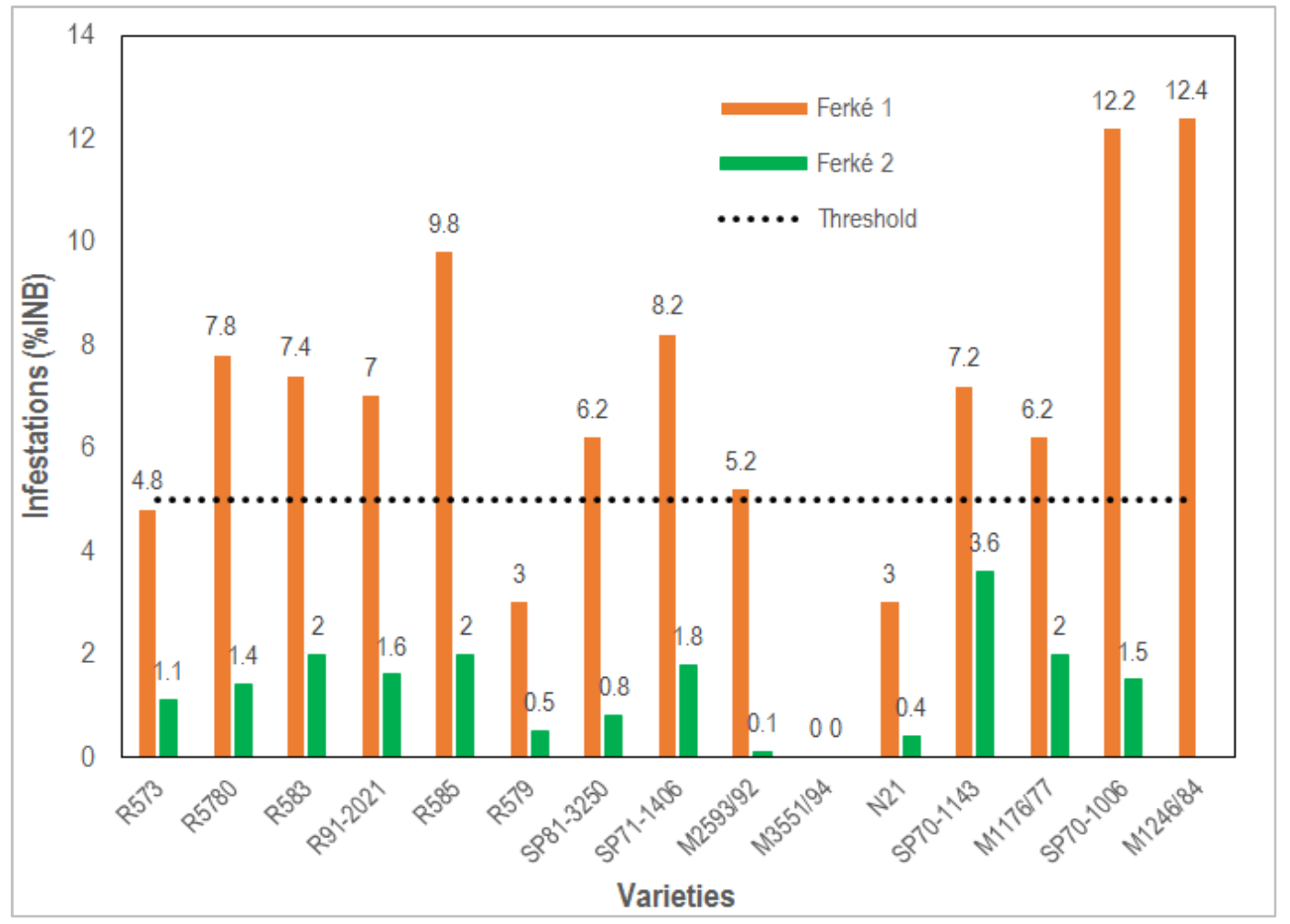

Figure 6. E. saccharina damage levels observed in sugarcane nurseries of Ferké 1 and 2 sugar mill plantations in 2016-17 on different varieties.

A significant reduction in stem borer damages was observed in 2017-18 for both Ferké mill plantations and particularly in Ferké $1(-1 \%)$ could be partly explained by lower rates of nitrogen fertilizer applied ( 25 to $30 \%$ reduction) in 2016-17 depending on crop cycle of plantations (plant cane or ratoon). This corroborates important differences in stem borer damages observed in 2016-17, due to nitrogen fertilizer rates, on same nursery varieties planted in both Ferké sugar mill plantations (Figure 6). High damage levels observed in 2017-18 on tolerant or resistant varieties such as R570, SP81-3250 and N21 over newly cleared plantations with richer soils in organic matter and nitrogen regarding four different sugar mill plantations in Ivory Coast (Ferké 1, Ferké 2, Borotou and Zuénoula), tend to confirm the excessive nitrogen rate as the main cause. Evidence of the relationship between nitrogen and E. saccharina damages was shown in South Africa by Atkinson and Nuss [28]. In Cuba, South America, findings of Lopez et al [29] on Diatraea saccharalis showed also that $\mathrm{N}$-fertilizer rates above $100 \mathrm{~kg} / \mathrm{ha}$ were responsible for a sudden increase of stem borer damages. These findings showed also that damage levels were higher when $\mathrm{N}$ application was done at early grand growth stage of sugarcane as internodes were tender for stem borer attacks. This corroborates findings of Goebel et al [19] obtained on two sugar mill plantations close to Durban (South Africa), which showed that industrial plantations subjected to higher $\mathrm{N}$-fertilizer rate $(134 \mathrm{~kg} / \mathrm{ha})$ were more damaged compared to only $50 \mathrm{~kg} / \mathrm{ha}$ for village plantations more healthy. A positive correlation between Nfertilizer rates and the percentage of cane stalks damaged was made which suggested that above $125 \mathrm{~kg}$ of N/ha stem borer attacks were intensified. According to Goebel et al [30], nitrogen is not only a yield factor in sugarcane but also a key element for the development stem borer larva. This explains the propensity of the insect female adult to lay its legs in leaf axils of cane stalks with high $\mathrm{N}$ content in order to maintain its life cycle.

As reported by several authors, silicon application in sugarcane grown on tropical weathered soils which are therefore poor in this element like on Ferké mill plantations, would enhance cane stalk resistance to stem borer damages [31-33] cited by Goebel et al [30]. It is estimated that the beneficial effect of silicon application on susceptible varieties to stem borer could prevent $20-30 \%$ of sugar yield losses due to E. saccharina, cane yield losses excluded [30]. This could explain improvement in the resistance of susceptible varieties to stem borer damages under water stress on rich soils in silicone by chemical changes in the concentration and structure of silicone within cane stalks. These changes could reinforce the barrier effect of stalk bark to the penetration of insect larva, although the hardness of cane tissues was not affected.

Influence of sugarcane varieties cultivated

Cane varieties known as susceptible to stem borer attacks 
in the agroecological context of Ferké are M1176/77, SP718210, SP75-184 and NCo376. They are characterized by sticking hold leaves on cane stems and stems with cracks which enhance the development of insect larva and their easy penetration into cane stalks. According to Goebel (2008), selection of resistant or tolerant varieties remain so far as the most successful method to control stem borer. He reported that the development of tolerant or resistant varieties to Diatraea saccharalis such as NCo310, CP52-68 and L62-96 resulted in significant reduction of infestations and therefore that of insecticide treatments [31]. Other works carried out in South Africa and Reunion Island have identified cane varieties resistant or susceptible to E. saccharina and $C$. sacchariphagus $[30,32]$. That is the case of R570 and R579 known as resistant and susceptible varieties, respectively [33]. Nevertheless, interactions between cane varieties and some farming conditions such as high $\mathrm{N}$ rates and water stress tend sometimes to reconsider the status of so called resistant or tolerant varieties. That was the case of R570 in Ivorian sugarcane growing areas as mentioned earlier. Similarly, certain varieties so called susceptible like R579 may escape heavy or moderate infestations as long as farming conditions remain optimum ( $\mathrm{N}$ fertilizer rate, soil water status) as it was observed during 2015-16 and 2017-18 cropping seasons in Ferké 2 sugarcane plantations (Figure 5)

Towards an integrated stem borer management strategy

Different studies on both main sugarcane stem borers showed their relative susceptibility to local agro-ecological conditions, including farming practices [34-38]. The regional workhop for west and central Africa on stem borer management held on late march 2018 in Ferké (Ivory Coast) allowed to sensitize main actors from height sugar companies on the relevance of implementing an integrated approach to effectively achieve that goal. It involves the use of resistant or tolerant varieties to stem borer attacks, a sound fertilizer application strategy, the plurality of landscapes required to increase faunistic and floristic biodiversity, farming practices preserving natural enemies of insect pests. It is the case of mechanized green harvesting of sugarcane with trash blanketing being practiced on both Ferké sugar mill plantations 10 years ago. Over the last four years, about $30 \%$ of Ferké sugarcane plantations i.e. 3600 ha are subjected to that practice. If agro-ecological control of pests as opposed to classical control cannot respond faster, it can assure a sustainable crop protection against stem borer while preserving the environment. In this regard, foliar applications of silicon fertilizer and the installation of light traps against stem borer at different critical sites within sugarcane plantations should mark the next cropping seasons in Ferké.

\section{Conclusion}

The study was motivated by the importance of stem borer (E. saccharina) damages observed at harvest in Ferké sugarcane plantations over the last three cropping seasons (2015-16 - 2017-18). The objective was to analyze these damage levels in order to determine their causes and recommend an appropriate pest management strategy. It came out that over the period of study (2006-07 to 2017-18), borer damages broke out during the last three and two years in Ferké 1 and Ferké 2, respectively. The findings confirm results obtained in different countries on other stem borer species. Many agronomic factors like cane varieties, nitrogen and silicon fertilizer applications are key elements in agroecological management of $E$. saccharina populations. Furthermore, any factor which may control stem borer populations such as their natural enemies (parasitoids, predators) using farming practices in sugarcane like mechanized green harvesting and cultivation of service plants in the vicinity of cane plantations is suggested. This later practice enhances biodiversity, soil fertility and therefore soil fauna in creating favorable conditions for controlling stem borer populations. Actions will be reinforced in this direction in years to come, which will be associated with a tight monitoring of stem borer population dynamics with light traps within sugarcane plantations targeted by this pest.

\section{References}

[1] Goebel FR, Beuzelin JM, Way MJ, 2018. Progress in understanding and managing insect pests affecting sugarcane. In: Achieving sustainable cultivation of sugarcane. Vol 2: Breeding, pest and diseases. P Rott (eds), University of Florida, Burleigh Dodds series in Agric. Sci.: 363-94.

[2] Kleynhans, Barton MG, Conlong DE, Terblanche JS, 2017. Population dynamics of Eldana saccharina Walker (Lepidoptera: Pyralidae): application of a biophysical model to understand phonological variation in an agricultural pest. Bull. Entomol Res. 108: 283-294.

[3] Potgieter L, Van Vuuren JH, Conlong DE, 2016. Simulation modelling as a decision support in developing a sterile insectinherited release strategy for Eldana saccharina (Lepidoptera: Pyralidae). Florida Entomol. 99(1)13-22.

[4] VanWeelden MT, Wilson BE, Beuzelin JM, Reagan TE, Way MO, 2016. Impact of nitrogen fertilization on Mexican rice borer (Ledoptera: Crambidae) injury and yield in bioenergy sorghum. Crop Protection 84: 37-43.

[5] Juma G, Ahuya PO, Ong'amo G, Ru B1, Magoma G, Silvain JF, Calatayud PA, 2015. Influence of plant silicon in Busseola fusca (Lepidoptera: Noctuidae) larvae - Poaceae interactions. Bull. Entomol Res. 105: 235-8.

[6] McFarlane SA, Govender P, Rutherford RS, 2009. Interactions between Fusarium species from sugarcane and the stalk borer, Eldana saccharina W (Lepidoptera: Pyralidae). Ann. Appl. Biol. 155: 349-359.

[7] Leslie GW, 1994. Observations on crop damage and larval populations of the pyralid borer Eldana saccharina in the sugarcane varieties NCo376 and N11. In: Proceed. South African Sugarcane Technol. Assoc. 68: 12-15.

[8] Berry SD, Leslie GW, Spaull VW, Cadet P, 2009. Withinfield damage and distribution patterns of stalk borer, Eldana saccharina W (Lepidoptera: Pyralidae), in sugarcane and comparison with nematode damage. Bull. Entomol. Res. 100: 373-385. 
[9] Betbeder-Matibet M, 1983. Eldana saccharina W (Lepidoptera: Pyralidae), foreur des tiges de canne à sucre en Afrique : dynamique de ses populations dans les plantations, comportement larvaire et recherche de moyens de lutte. $\mathrm{PhD}$ Thesis, ENSA Montpellier, France.

[10] Conlong DE, 1994. A review and perspectives for the biological control of the African sugarcane stalkborer Eldana saccharina W (Lepidoptera: Pyralidae). Agric. Ecosyst. Environ. 48: 9-17.

[11] Atkinson PR, 1981. Mating behavior and activity patterns of Eldana saccharina W (Lepidoptera: Pyralidae). J. Entomol. Soc. South Afr. 44: 265-280.

[12] Atkinson PR, Carnegie AJM, 1989. Population dynamics of the sugarcane borer, Eldana saccharina W (Lepidoptera: Pyralidae). Bull. Entomol. Res., 97: 489-506.

[13] Atkinson PR, Nuss KJ, 1989. Association between host-plant nitrogen and infestations of the sugarcane borer Eldana saccharina Walker. Bull. Entomol. Res. 79: 61-80.

[14] Keeping MG, 2006. Screening of South African sugarcane cultivars for resistance to the stalk borer, Eldana saccharina W (Lepidoptera: Pyralidae). Afr. Entomol. 14: 277-288.

[15] Goebel FR, Sallam N, 2011. New threats for sugarcane in the new bioeconomy and how to manage them. Current Opinion in Environ. Sustain. 3: 81-9.

[16] Péné CB, Kouamé KD, Dove H, Boua BM, 2016. Incidence des infestations du foreur de tiges Eldana saccharina W (Lepidoptera : Pyralidae) en culture irriguée de canne à sucre selon la variété et la période de récolte en Côte d'Ivoire. $J$ Appl. Biosci. 102: 9687-9698.

[17] Kouamé KD, Péné CB, M Zouzou, 2010. Évaluation de la résistance variétale de la canne à sucre au foreur de tiges tropical Africain (Eldana saccharina W) en Côte d'Ivoire. $J$ Appl. Biosci. 26: 1614-1622.

[18] Kvedaras Ol, Keeping MG, Goebel FR, Byrne M, 2007. Water stress augments silicon-mediated resistance of susceptible sugarcane cultivars synergy in resistance of sugarcane cultivars to stalk borer, Eldana saccharina Walker (Lepidoptera: Pyralidaea). Bull. Entomol. Res., 97: 175-183.

[19] Goebel FR, Way MJ, Gossard B, 2005. The status of Eldana saccharina (Lepidoptera: Pyralidaea) in South African sugar industry based on regular survey data. Proc South Afr Sugarcane Technol. Assoc, 79: 337-346.

[20] Lopez E, Fernandez C, Lopez O, 1983. Effect of nitrogen fertilisation on Diataea saccharalis (Fabr.) incidence on sugarcane. Proceed. Intern. Soc. Sugarc. Technol. 18: 910-914.

[21] Way MJ, Goebel FR, Gillespie W, 2003. Surveying Eldana saccharina (Lepidoptera: Pyralidaea) in a small-sacale grower sector of the South African sugarcane industry. Proceed. South Afr. Sugarc. Technol. Assoc. 77: 275-277.

[22] Paxton RH, 1982. Eldana borer (E. saccharina): the results of surveys. Proceed. South Afr. Sugarc. Technol. Assoc. 56: 99-103.

[23] Konan EA, Péné CB, Dick E, 2017a. Main factors determining the yield of sugarcane plantations on Ferralsols in Ferké 2 sugar complex, Northern Ivory Coast. J. Emerg. Trends Engineer. Appl. Sci. JETEAS 8(6): 244-256.

[24] Konan EA, Péné CB, Dick E, 2017b. Caractérisation agro- climatique du périmètre sucrier de Ferké 2 au Nord de la Côte d'Ivoire. J Appl. Biosci. 116: 11532-11545.

[25] Péné CB, Ouattara HM, Koulibaly GS, 2012. Late season sugarcane performance as affected by soil water regime at the yield formation stage on commercial farms in northern Ivory Coast. J Life Sci. 6(6): 644-651.

[26] Hoarau M, 1970. Utilisation de la presse hydraulique pour le détermination de la richesse saccharine de la canne à sucre. In La Canne à sucre. IRAT. Fauconnier et Bassereau, Maisonneuve et Larose (eds): 387-419.

[27] Fauconnier R, 1991. La canne à sucre. Le technicien d'agriculture tropicale. Maisonneuve et Larose (eds). 165 p.

[28] Goebel FR, Way M, Conlong D, 2008. La gestion des foreurs de la canne à sucre, l'environnement et les pratiques culturales: synthèse des résultats et perspectives. In: Actes Congrès sucrier ARTAS-AFCAS 2008, La Guadeloupe: 1-12.

[29] Wang MQ, 2005. Effect of complete silicon fertilizer on rice yield. Acta Agric. Shanghai 21: 71-73.

[30] Keeping MG, Meyer JH, 2002. Calcium silicate enhances resistance of sugarcane to the African stalk borer Eldana saccharina W (Lepidoptera: Pyralidae). Agricul. Forest Entomol. 4: 256-74.

[31] Meyer JH, Harding R, Rampersad AL, Wood RA, 1998. Monitoring long term soil fertility trends in the South African sugar industry using the FAS analytical database. Proceed. S. Afr. Sug. Technol. Assoc. 72: 61-68.

[32] Hensley SD, Fanguy HP, Giamalva MJ, 1977. The role of varietal resistance in control of the sugarcane borer Diatraea saccharalis (F.) in Louisiana. In: Proc. Intern. Soc. Sug. Technol. 16: 517-522.

[33] Keeping MG, Rutherford RS, 2004. Resistance mechanisms of South African sugarcane to the stalk borer Eldana saccharina (Lepdoptera: Pyralidaea): A review. In: Proc. S. Afr. Sug. Technol. 78: 307-11.

[34] Goebel FR, Fernandez E, Begue JM, Tbère R, Alauzet C, 2000. Predation and varietal resistance as important components of integrated protection of the sugarcane stem borer Chilo sacchariphagus Bojer in Réunion Island. In: Sugarcane Pest Management in the new millennium. ISSCT Entomology Worlshop: 51-59.

[35] Nikpay A, Kord H, Goebel FR, Sharafizadeh P, 2014. Assessment of natural parasitism of sugarcane moth borer Sesamia spp by Telenomus busseolae in five commercial cultivers. Sugar Technol. 16(3): 325-8.

[36] Parra JRP, Botelho PSM, Pinto AS, 2010. Biological control of pests as a key component for sustainable sugarcane production. In: L. A. B. Cortez (eds), Sugarcane Bioethanol: Rand for Productivity and Sustainability, SP, Brazil: 441-50.

[37] Goebel FR, Tabone E, Do Thi Khanh H, Roux E, Marquier M, Frandon J, 2010. Biocontrol of Chilo sacchariphagus (Lepidoptera: Crambidae) a key pest of sugarcane: lessons from the past and future prospects. Sugarc. Intern. 28: 128-32.

[38] Do thi Khanh H, Gobel FR, Marquier M, Fandon J, Roux E, Clain C, Colomel E, Tabone E, 2012. Contrôle biologique du foreur ponctué de la canne à sucre à la Réunion par lâchers inondatifs de trichogrammes : Étapes franchies pour un développement à grande échelle. Proceed. Congrès sucrier AFCAS-ARTAS 2012, La Réunion: 1-11. 